Zaitseva, V. \& Buihasheva, A. (2021). Ukrainian book design: ways of formation and development. Culture and arts in the context of cultural heritage. Klironomy, 3 (3), 108-119. Hlučín-Bobrovníky: "Anisiia Tomanek" OSVČ.

Зайцева, В.І., Буйгашева, А.Б. (2021). Український дизайн книги: шляхи формування і розвитку. Culture and arts in the context of cultural beritage. Klironomy, 3 (3), 108-119. Hlučín-Bobrovníky: "Anisiia Tomanek" OSVČ.

DOI: $10.47451 /$ art2021-10-004

EOI: $10.11249 / \operatorname{art} 2021-10-004$

The paper is published in Crossref, Internet Archive, ICI Copernicus, Google Scholar, Academic Resource Index ResearchBib, JGate, ISI, CiteFactor, Journal Factor, eLibrary, Ukrainian National Library databases.

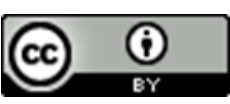

Veronika Zaitseva

Candidate of Art History

Associate Professor

Department of Fine Arts

Institute of Arts

Kyiv University named after Boris Grinchenko

Kyiv, Ukraine

E-mail:v.zaitseva@kubg.edu.ua,nika.zaytseva@gmail.com

ORCID: 0000-0003-1160-1760

Alla Buihasheva

Professor

Department of Fine Arts

Institute of Arts

Kyiv University named after Boris Grinchenko

Kyiv, Ukraine

ABB10@i.ua

ORCID: 0000-0002-4716-3144

\title{
Ukrainian book design: ways of formation and development
}

\section{Abstract:}

In the Ukrainian graphic art development of the 20th century as a whole and specific art events and artistic works, a constant interaction of international and national, general and specific, modern and traditional is traced. The development of the new graphic art was especially influenced by the revaluation of the aesthetic qualities of national art. The research purpose is to study the development of the directions of Ukrainian book art, the formation of new creative features in the European cultural space. The research methodology consists of the general scientific methods application (analysis and synthesis, induction and deduction) and methods of art history (comparative, typological, descriptive). The scientific novelty lies in the study of book design, which has always been significant in Ukrainian art. Today, we have many fine works in the genre of book illustrations. These works reflected both the history of Ukrainian literature, the history of the national graphic art, as well as the history of cultural progress of Ukraine in general. Thus, book design is an extremely fruitful object of study, an intersection points in which the complicated process of the interaction of social, political, spiritual, cultural and artistic and aesthetic factors is 
underway. The Ukrainian graphic art of those days reflected different all-European trends, e.g., modernism, symbolism, neo-primitivism, futurism, cubism, expressionism, constructivism, realism, surrealism, Art Deco, neoclassicism. The originality of the artistic language emerged through the use of traditional motifs and vanguard image creation tools.

Keywords: research, culture, illustration, images, book, art, national traditions.

\section{Вероніка Іванівна Зайцева}

КандиАат мистецтвознавства

Аоцент кафедри

Кафелра образотворчого мистецтва

Інститут мистецтв

Київський Університет імені Бориса Грінченка

Київ, Україна

E-mail:v.zaitseva@kubg.edu.ua,nika.zaytseva@gmail.com

ORCID: 0000-0003-1160-1760

\section{Амха Борисівна Буйгашева}

Професор кафедри

Кафелра образотворчого мистецтва

Інститут мистецтв

Київський Університет імені Бориса Грінченка

Київ, Україна

ABB10@i.ua

ORCID: 0000-0002-4716-3144

\section{Український Аизайн книги: шияхи формування і розвитку}

\section{Aнотачія:}

Метою статті є АосліАження розвитку напрямів українського книжкового мистецтва, формування нових творчих рис у європейському культурному просторі. Методологія АосліАження полягає у застосуванні загальнонаукових методів (аналіз і синтез, індукція та дедукція) та методів мистецтвознавства (порівняльний, типологічний, описовий). Наукова новизна полягає у вивченні книжкового дизайну, який завжди був важливим в українському мистецтві. Сьогодні ми маємо велику кількість прекрасних робіт у жанрі книжкової ілюстрації. Ці твори вілбили як історію української мітератури, історію вітчизняної графіки, так і історію культурного прогресу України загалом. Отже, книжковий дизайн є надзвичайно пліАним об’єктом досліАження, точкою перетину, Ае віАбувається складний процес взаємодії суспільно-політичних, духовних, культурно-мистецьких та естетичних чинників. Українська графіка того періоду відображала різні загальноєвропейські течії - модернізм, символізм, неопримітивізм, футуризм, кубізм, експресіонізм, конструктивізм, реалізм, сюрреалізм, арАеко, неокласицизм. Своєрідність художньої мови виникла завдяки використанню традиційних мотивів та авангардних засобів створення образів. 
Ключові слова: АосліАження, культура, ілюстрація, образи, книга, мистецтво, національні традиції.

\section{Introduction}

The history of the book design art has proved that illustrations have been considered significant for centuries, as vivid pictures were the only effective way of opening text information to semi-literate readers. The illustrations, done in a peculiar artistic interpretation, not only accompanied the text of literary works but also complemented it to a large extent, revealing the basic plot outline.

The first third of the 20th century revives a book as a complex artistic phenomenon - the synthesis phenomenon symbolizing a new attitude. The creative experience has been accumulated over the years. The book illustration involved more and more talented artists whose creative achievements determined the face of the Ukrainian book design at various stages of its evolution. Until recently, by the established tradition, the history of Ukrainian art has been divided into the Soviet and pre-October periods. In the author's opinion, this periodization has the right to continued existence, even because of general trends in thematic works of art, like artistic tasks in the field of figurative and stylistic quest dictated by time to artists. This concept has combined the heritage of rather different artists, whose work not only matches the designated period but differs by a fundamentally new outlook, a new style and the new aesthetic development and expressive means of implementing the chosen artistic theme. Considering the overall development process of the Ukrainian book, we conclude that, at various stages of its history, book artists always faced more or less the same, common technical and artistic challenges, which were resolved over the centuries at an ever-growing artistic and aesthetic level.

In-depth research of Ukrainian art, critics-researchers analyze how artistic tastes and styles have changed in the registration process of literary works, revealed different schools, directions, features of the creative method and style of famous artists. This is stated in the works of such well-known scientists as: O. Avramenko, Y. Belichko, V. Bokan, B. Valuenko, M. Gordiychuk, M. Kryvolapov, O. Lagutenko, O. Lamonova, D. Malakov, L. Polevoy, O. Fedoruk, A. Shpakov and others.

Ukrainian graphic artists captured the rich heritage of the past centuries. It should note that the art of book design of the first third of the 20th century is marked with the constant interaction of international and national, general and traditional vision. 


\section{Art research in the Ukrainian book design of the first third of the 20th century}

The works of the Ukrainian book design of the first third of the 20th century widely "travelled" in Ukraine and fell abroad. They were not created in the situation of the "iron curtain". Ukrainian artists worked in Paris, Munich, Leipzig, Prague, Warsaw, Krakow, Moscow, St Petersburg. The Ukrainian graphic art language was influenced by traditions and new trends of West European, Russian and Polish art, like national artistic sources. Being intertwined in the work of each artist, they are hard to be distinguished (Lagytenko, 2003).

In the early 20th century, a new interest arose among book masters as to individual features of each book as a whole, fonts and ornaments on the covers and in the text. The book artists increased demands towards the creation of their own "handwriting" in fonts, tending to the national identity.

Any progress in this direction could be achieved only through an analytical analysis of the classical heritage. The real life-giving source for Ukrainian artists was the wealth of technical and artistic achievements of old national publications, like the high publishing culture of the countries of Western Europe.

Illustrations by famous Ukrainian book designers P. Martynovych, J. Yizhakevich, G. Narbut, V. Kasian, M. Deregus, A. Dovhal, S. Adamovich, A. Danchenko, D. Yakutovych and many other artists of the twentieth century were marked with a variety of art styles and an organic interplay with literary texts.

The foundation of the Ukrainian Academy of Arts became the most significant event in the artistic life of Ukraine in the 1910s, the hugest achievement of the cultural policy of the new government of the Ukrainian National Republic (UNR). Invited to join the teaching staff structure of the first National Academy of Arts were famous masters, with an inherent common desire to combine old traditions of Ukrainian art with new discoveries of European artistic movements. In visual arts, the founders of the new school went through the art nouveau style, with its attraction to the synthesis of arts.

The Graphic Art Workshop of the Ukrainian Academy of Arts was led by George Narbut, a recognized book design professional. The attractiveness of Narbut's creative works, the accuracy of his plastic solutions, exquisite taste and knowledge of artistic styles contributed to the artist recognition as the idol of graphic artists for many years. He launched the most extensive and influential trend in Ukrainian graphic art of the 1920s, dubbed "Narbut Trend" (Valyenko, 1976:105). 
George Narbut was inspired by a dream to revive the high status of art, which it had in antiquity. An example of deep immersion in human life and traditions was folk art, characterized by certain canons and conventions, passion for bright colours and immediacy attitude, avoidance of external descriptiveness.

The artist set himself a complex task of finding a popular style that would enable to combine the traditional and new form capacious content and universal qualities. The plastic language of G. Narbut in his Kyiv period gradually changes, compared to the previous one - that of St Petersburg. The artist turns to samples of old Ukrainian book printing, which is already evident in the cover design for the first issue of the magazine "Our past", 1918. Narbut could easily implement figurative motifs in symbolic compositions.

For 20 years, the workshop has brought up a whole galaxy of book artists. From year to year, the skills of its graduates kept growing, the genres of the books, illustrated by its diploma holders, expanded, the most sophisticated graphic techniques were mastered, and the book culture and imagery of the graphic form improved. During that period, art education developed according to the requirements of national publishing practices and artistic life, learning everything new and progressive (Yanson \& Yanson, 1996:152).

Today, there is a need for a new interpretation of the history of the Ukrainian graphic art of the twentieth century within the lines of the all-European artistic process. The Ukrainian graphic art of the 20th century has always been the focus of art history for both scientific researchers and art critics. Being intelligent, technically verified, to some extent free of political bias, it remained for the stormy century a zone of artistic freedom.

Though the teaching of the history of the art of the twentieth century was always under close censorship. Any research of the "formalistic tendencies", along with national features, was not encouraged, and many artists' names of the first third of the 20th century were entirely struck off history (Lagytenko, 2003:102).

\section{Cultural prerequisites for flowering of the graphic art}

In the early 20th century, graphic art underwent a real renaissance. Artists set many tasks for the form of art: both purely artistic, philosophical, and social and social and political. Magazine and book design, drawings for newspaper editions, posters - these forms of graphic creativity gained priority in the development of art in its osculation with the surrounding fluid life.

It is the graphic art that exists on the brink of individually unique and replicable mass art, gained a new impetus due to the advance in the printing production field. 
The graphic art reflected the problems faced by artists at the turn of the century and was perceived by them as a clash of opposites - elite and mass, hand-made and replicated, material and spiritual, novel and traditional (Lagytenko, 2011).

In the late 19th century, some common trends were tangible in the culture of various European countries, and those trends ideologically emanated from two main reasons - the crisis of positivism and the desire to open up new dimensions in attitude to the surrounding world and the life process in general. Nowadays, there are grounds to form a common field of culture.

The correlation of "international" and "national" in art was one of the topical issues raised by Art Nouveau masters. Advocates of the new style manifested versatility of its formative tools, though the desire to restore some national traditions was no less significant for artists and architects. Forms are interspersed with colour fragments and space between them according to the specific aesthetic or spiritual task (Aseeva, 1995:25).

At the turn of the 19th and 20th centuries, in Ukraine, the graphic art flourishing was facilitated by the fact that several significant components synchronized in the development of artistic situation: the rise of national cultural movement, strengthening of the ideas of the "new" art, denying the usual mimesis and proliferation of symbolism and Art Nouveau.

The «compression» of the transition period led to both rapid development of the graphic art and a complication of the adaptation process of new tendencies, as well as the parallel existence of a large number of different events and trends.

The artistic life activation was caused by the new economic development stimulating urban culture mainly. The number of large cities in Ukraine increased. It was the time of the new museums' creation, exhibition salons, creative associations, which, in turn, triggered the emergence of new art periodicals. The artists felt their involvement in the single artistic process that embraced Europe then.

The training process and creative trips immersed young Ukrainian artists in the Paris, Vienna, Munich, Krakow, Moscow, St Petersburg artistic life. Cooperation with Polish and Russian art turned to be a particularly significant factor in the Ukrainian culture development at the turn of the 19th and 20th centuries.

From 1904 to 1914, the Association of Friends of Ukrainian literature, science and a piece» existed from 1904 to 1914. A major exhibition, launched as the First Nationwide Exhibition (1905), was the most significant event in its artistic policy. The exhibition presented the works of masters of the Western and Eastern Ukraine, a new generation of artists, including Ivan Trush, M. Sosenko, M. Zhuk, M. Burachek and M. Boychuk. 
In 1905, the first Ukrainian-language art journal "The Artistic Herald", founded by Ivan Trush, was launched in Lviv. A great mission of improving the artistic situation in Ukraine was fulfilled by newspapers "Iris" (1899-1900), "Buduchnistj" (1899), "Moloda Ukrayina" (1900-1903), "Liberum Voto" (1904-1905) and "Nasz Kraj" (1906-1910).

The magazines provided an opportunity to use the tools of printing production to implement and disseminate artistic ideas. They put technology at the service of art; thanks to the decoration of the magazines, the individual, unique graphic art produced a huge circulation (Lagytenko, 2003).

The new magazines enjoyed the willing cooperation of the artists who professed the Art Nouveau style, such as T. Terletsky. In the style of Art Nouveau at that time, books and posters of K. Sikhulsky, S. Dembitsky, E. Okun, E. Liliyen, etc. were designed. The national or "Hutsul" version of the Art Nouveau was developed by I. Severin. The Hutsul themes were turned to by K. Sikhulskyy and V. Yarotskiy. The love for decorative ornamentation is inherent in the creative works of $\mathrm{H}$. Koltsunyak. Referred to by researchers as "Lviv Maurice" is M. Olszewski, who became the founder of the association "Zespul".

Art Nouveau gave many examples of theatrical presentations and enhanced the accentuation of oriental themes and motifs. Quite often, artists created their imaginary East. In Lviv secession, Oriental themes found their vivid expression in the illustrations of I. Kosynin and the paintings and graphic works of K. Stefanovich, who relied on the traditions of Indian, Persian and Armenian arts, and used the iconographic designs of the Ukrainian iconography (Lagytenko, 2003).

The ancient Ukrainian and Byzantine art traditions were turned to by M. Sosenko and J. Pankevych, and later by M. Boychuk. The New Byzantism got a foothold as one of the areas of secession. The attraction to medieval ideas, characteristic of the aesthetics of the turn of the century, was tied to the ideas of national revival of Symbolism and Art Nouveau.

\section{The trend of neo-primitivism in the Ukrainian graphic art}

The existence of independent graphic schools in Kyiv, Kharkiv, Odesa, Lviv and their interaction contributed to creating the unified field of Ukrainian graphic art. Despite political and ideological boundaries, common trends and directions manifested themselves in this unified field. The multi-layer cultural space absorbed various trends, traditions and innovations, developing a unique image of such a phenomenon as the graphic art of Ukraine of the 1920s to early 1930s. 
Neo-primitivism may be recognized as the most persistent and common trend in the Ukrainian graphic art of the day. This was facilitated by many factors, notably, the impact of the global democratization processes, which took place in the culture at the turn of the 19th and 20th centuries. After several revolutions in the Russian Empire, they not only became legitimate but were imposed on society.

For the art of the early twentieth century, the opening of the cultures of the primitive society, revaluation of the gains of medieval Europe and the East, archaeological findings in Egypt, Mesopotamia and India, gave a powerful impulse to the search for a new artistic language. On the way to this, the ideas of M. Boychuk, who was recognized in Ukrainian art as the discoverer of the neo-primitivism trend, met the needs accentuated by symbolism artists and writers. The desire to open the viable sources of art, which would involve all those seeking to know the truth in the existing world, was passionate and urgent. For M. Boychuk, M. Sosenko, Y. Pankevych and their followers the icon became an example of this work of art (Lagytenko, 2011).

Boychuk paved the way from the Art Nouveau to the Avant-Garde. He opened the aesthetic value of popular prints, urban primitive. M. Boychuk, as a professional artist, who was educated at several academic art institutions, reevaluated the artistic heritage of ancient cultures, the latest discoveries of Avant-Garde artists and merged them with the tradition of Ukrainian iconography, with the popular image and urban primitive.

The next step in the neo-primitivism development in Ukrainian graphic art was its fruitful processing and creative development by S. Nalepynska-Boychuk, I. Padalka and their apprentices' disciples and followers. Neo-primitivism developed its ways of modernizing the traditional forms and processing "non-classical" ancient cultures methods, to use them in transmitting the modern sense.

The Neo-primitivism trend of the 1920s was rather broad, it was filled with art phenomena in various plastic forms. Those were watercolours of M. Sinyakova, bright and narrative as a folk fairy tale, restrained-lyricism drawings by M. Boychuk, intricate-nature ink drawings by I. Mozalevskyi, "cheap-popular" linocuts by I. Padalka and M. Fradkin, "vybiychani” carvings by A. Kulchytska. The signs of neoprimitivism are found in the works of V. Krichevsky, H. Narbut, S. NalepynskaBoychuk, T. Boychuk, O. Pavlenko, V. Sedliar, M. Kotlyarevska, M. Yunak, S. Colos, O. Ruban, Y. Sagaydachnyi, M. Zhuk, P. Kovzhun, M. Butovych, I. Ivanov, O. Dovhal and even V. Kasian (Lagytenko, 2011).

The growing influence of old prints marked the early work of O. Sakhnovska. The language of primitive was enhanced by the use of rhythm and plastic language 
tools of expressionism. However, Sakhnovska created multi-figure genre compositions in a narrative realistic manner.

\section{Cubo-Futurism, Constructivism, Art Deco}

Unlike the polistylism of the Narbutov trend, a pure stylistic line in Ukrainian graphic art was adhered to by Cubo-Futurism. Cubo-Futurism, as a trend in Ukrainian art, opened by O. Bogomazov and O. Exter, was echoed in the 1920s in V. Yermylov, M. Epstein, V. Meller, A. Petrytsky, B. Kosarev and A. HvostenkoKhvostova works. This stylistic trend was vivid expressly not only in the easel, book and magazine graphic arts but also in sketches of theatrical costumes and scenery, which were created as valuable-by-themselves works and were often exhibited at art exhibitions and published in magazines and monographs.

In the 1920s, V. Krychevsky continued his work in the book design. In his works of this period, you will notice the signs of various artistic trends: neotraditionalism, neo-primitivism, expressionism, constructivism, synthetic realistic art and Art Deco style.

Along with V. Yermylov, V. Krichevsky was the founder of constructivism in Ukrainian graphic art. Constructivism became one of the main directions of the Ukrainian avant-garde. Constructivism combined the graphic art in the book and the arts of geometric abstraction and font. In addition, it affected the formal decisions as to the internal organization of the text set, appropriate use of image-bearing possibilities of printing items.

The constructivist trend of the 1920s to the early 1930s brought to life a galaxy of artists: V. Meller, N. Henke-Meller, H. Tsapok, Geo Fisher, A. Petrytsky, B. Sokolov. Some works, those of A. Strakhov, I. Padalka, I. Pleschynsky, S. Hordynsky, followed the aesthetics of constructivism. The artists, while following this trend, worked at the artistic book design, a magazine, a wall newspaper, industrial graphic art in its numerous forms and purposes (Lagytenko, 2011).

\section{Expressionism and Surrealism}

Expressionism, inherent in the works of a large group of artists, was an outstanding event in Ukrainian graphic art. Expressionism has affected the book and easel works by M. Butovych, M. Osinchuk, M. Fedyuk, Y. Muzika, O. Sorokhtey, L. Hets, O. Dovhal, A. Petrytskyi, V. Kasiyan, Z. Tolkachev, V. Ovchinnikov.

This Ukrainian graphic art trend was initiated by M. Sinyakova in 1916. Eminent expressionist works were done by Bukovina artists A. Kolnyk and L. Kopelman. Masters M. Fedyuk and M. Osinchuk, who worked mainly in Lviv, in their 
expressionistic works, relied on medieval art tradition, continuing the neo-byzantine line. The biblical theme was leading in A. Sorohtey's works. Working in the woodcut technique, the artist performed an image with lightning-like white strokes on a black background.

Many of the graphic works by Y. Muzika, created in the early 1930s, also belong to expressionism. Close to expressionism are easel graphic works by L. Hets and L. Levitsky (Lagytenko, 2011).

There are examples of surrealism among stylistic trends variety in the Ukrainian graphic art of the 1930s. Compositions by Lviv masters O. Ghana and L. Lilleh and Kharkiv artists S. Ioffe and O. Shcheglov are also samples of surrealism.

In Ukrainian art, including graphic art, the plastic experiments' attraction was combined with an appeal to traditions of such artistic phenomena as Boychukism, Narbut Trend, caused by the national recovery time. In the case of the 1930s, the synthesis took place on a different basis - realism.

The figurative graphic compositions, which, by their language, already met the realism standards, though still holding the formal achievements of the latest trends, at the time, were the objects of graduates works of the Kiev, Kharkiv and Odesa Art Institutes, like famous artists as M. Kotlyarevska, H. Pustoviyt, B. Blank, M. Fradkin, J. Dayts, D. Shavykin, H. Bondarenko, O. Dovhal, B. Friedkin, L. Kaplan, S. Nalepynska-Boychuk, O. Sakhnovska, O. Ruban, V. Kasiyan, T. Moskaleva, Y. Fartukh, O. Shovkunenko, B. Kryukov, Y. Leus, H. Zolotov.

The graphic art of the first half of the 20th century does not follow the ways strictly specified to it. Artists offer different answers to the orders of the customer state. But indicative is the difference between neo-classical art and socialist realism when the interference of ideology qualitatively changes the attitude to the tradition of classical realism and its processing, the art enters the sphere of attraction of other values. The environment changes, thus leading to qualitative changes in all art development processes.

\section{Discussion}

The relevance of research on this topic is the study of book design in the development of modern Ukrainian book art.

Thus, book design is an extremely fruitful object of study, a point of intersection where a complex process of interaction of socio-political, spiritual, cultural, artistic and aesthetic factors takes place. Thus, modern Ukrainian graphics continue the creative interaction of international and national, general and traditional vision. 
The modern process of development of Ukrainian books has common European artistic tasks, which are solved at a growing artistic and aesthetic level.

This is stated in the works of such modern scientists as: Olesya Avramenko, Natalia Belichko, Olga Lagutenko, Kateryna Popovych, Roman Yatsiv.

\section{Conclusion}

Based on the above, applied and easel graphic art of the first third of the twentieth century is an integral, fundamentally new phenomenon in the history of Ukrainian art, whose development is conditioned by the active national cultural movement. Artists were inspired by the belief in the social, ethical, effective mission of art. The magazine and book design, posters, applied crafts and easel graphic art flourished unprecedentedly thanks to the active dialogue with the surrounding fluid life.

The graphic art phenomenon exists in wars and revolutions situations, national rebirth and economic devastation, on the verge of chaos and order. The Ukrainian graphic art of the designated time shows a combination of All-European artistic trends and national characteristics of the artistic process.

A particular interest in graphic art emerged in the early twentieth century under the influence of a new ideology, where a significant role was played by the ideas of the Art Nouveau style. Masters, who practised the ideas of this style in the art, regarded graphic art as an art branch, which possessed immense capabilities of the plastic language, that would enable stepping up the progress towards greater conditionality of image-bearing solutions and realizing the desired synthesis of art and life.

Ukrainian art cooperation with Poland and Russia was a significant factor in the graphic art development in Ukraine in the early twentieth century. Some impulsive progress was observed through regular contacts, exhibitions, Polish and Russian artists work in Ukrainian cities, through the personal creative influence of those artists who had taught Ukrainian artists.

Despite all the complexity in which Ukrainian art found itself in the conditions of the first half of the last century, the creative intelligentsia understood the importance of the aesthetic aspect concerning the process of formation of the "new art". The aesthetic ideas, anyway, are present in almost all the master's practitioners works of Ukrainian art. One of the challenges facing the young Ukrainian scientists is to further research, systematization and introduction into the wide scientific use the aesthetic heritage of outstanding masters' practitioners of the Ukrainian graphic art of the first half of the last century. 


\section{References:}

Aseeva, N. (1995). Studies of Art History. Ukrainian Cultural Almanac Chronica-2000, 2-3. Kyiv. (in Ukrainian)

Hylenson, P.H. (1978). Technical Editor's Reference. Kyiv. (in Ukrainian)

Lagytenko, O.A. (2011). Ukrainian graphics of the 20th century. Kyiv: Grani-T. (in Ukrainian)

Lagytenko, O.A. (2003). Ukrainian graphics of the first third of the 20th century. Kyiv: Grani-T. (in Ukrainian)

Levchuk, L. (2009). Futurism: history, theory, artistic practice. Actual philosophical and cultural problems of modernity. Collection of scientific articles, 24. Kyiv. (in Ukrainian) Lyakhov, V.N. (1971). Essays on the theory of the art of the book. Moscow. (in Russian)

Palmov, V. (2005). About my work. Ukrainian avant-gardists as theorists and publicists. Kyiv. (in Ukrainian)

Shpakov, A.P. (1973). Artist and book. Kyiv: Mystetstvo. (in Ukrainian)

Sidorov, A.A. (1924). A book as an object of study. Book in Russia. (in Russian)

Valyenko, B.V. (1976). Book Architecture. Kyiv. (in Ukrainian)

Yanson, K. \& Yanson, E. (1996). Fundamentals of art history. St Petersburg. (in Russian)

Yul'ten, P. (1981). Paris - Moscow. Moscow - Paris. 1900-1930. Exbibition Catalog, June 3 - October 4, 1981. Moscow. (in Russian) 